University of Nebraska - Lincoln

DigitalCommons@University of Nebraska - Lincoln

Regional Patterns in the Isotopic Composition of Natural and Anthropogenic Nitrate in Groundwater, High Plains, U.S.A.

\author{
P. B. McMahon \\ United States Geological Survey, pmcmahon@usgs.gov \\ J. K. Bohlke \\ United States Geological Survey
}

Follow this and additional works at: https://digitalcommons.unl.edu/usgsstaffpub

Part of the Earth Sciences Commons

McMahon, P. B. and Bohlke, J. K., "Regional Patterns in the Isotopic Composition of Natural and Anthropogenic Nitrate in Groundwater, High Plains, U.S.A." (2006). USGS Staff -- Published Research. 60. https://digitalcommons.unl.edu/usgsstaffpub/60

This Article is brought to you for free and open access by the US Geological Survey at DigitalCommons@University of Nebraska - Lincoln. It has been accepted for inclusion in USGS Staff -- Published Research by an authorized administrator of DigitalCommons@University of Nebraska - Lincoln. 


\section{Regional Patterns in the Isotopic Composition of Natural and Anthropogenic Nitrate in Groundwater, High Plains, U.S.A.}

P. B. $\mathrm{MCMAHON}^{*},{ }^{\dagger}$ A N D J. K. B ÖHLKE

United States Geological Survey, Lakewood, Colorado 80225, and United States Geological Survey, Reston, Virginia 20192

Mobilization of natural nitrate $\left(\mathrm{NO}_{3}{ }^{-}\right)$deposits in the subsoil by irrigation water in arid and semiarid regions has the potential to produce large groundwater $\mathrm{NO}_{3}{ }^{-}$ concentrations. The use of isotopes to distinguish between natural and anthropogenic $\mathrm{NO}_{3}{ }^{-}$sources in these settings could be complicated by the wide range in $\delta^{15} \mathrm{~N}$ values of natural $\mathrm{NO}_{3}{ }^{-}$. An $\sim 10000$ year record of paleorecharge from the regionally extensive High Plains aquifer indicates that $\delta^{15} \mathrm{~N}$ values for $\mathrm{NO}_{3}{ }^{-}$derived from natural sources ranged from 1.3 to $12.3 \%$ and increased systematically from the northern to the southern High Plains. This collective range in $\delta^{15} \mathrm{~N}$ values spans the range that might be interpreted as evidence for fertilizer and animal-waste sources of $\mathrm{NO}_{3}{ }^{-}$; however, the $\delta^{15} \mathrm{~N}$ values for $\mathrm{NO}_{3}{ }^{-}$in modern recharge $(<50$ years) under irrigated fields were, for the most part, distinctly different from those of paleorecharge when viewed in the overall regional context. An inverse relation was observed between the $\delta^{15} \mathrm{~N}\left[\mathrm{NO}_{3}{ }^{-}\right]$values and the $\mathrm{NO}_{3}{ }^{-} / \mathrm{Cl}^{-}$ratios in paleorecharge that is qualitatively consistent with fractionating losses of $\mathrm{N}$ increasing from north to south in the High Plains. $\mathrm{N}$ and $\mathrm{O}$ isotope data for $\mathrm{NO}_{3}{ }^{-}$are consistent with both $\mathrm{NH}_{3}$ volatilization and denitrification, having contributed to fractionating losses of $\mathrm{N}$ prior to recharge. The relative importance of different isotope fractionating processes may be influenced by regional climate patterns as well as by local variation in soils, vegetation, topography, and moisture conditions.

\section{Introduction}

Nitrate $\left(\mathrm{NO}_{3}{ }^{-}\right)$is one of the most common groundwater contaminants in the world and its presence in the environment at elevated concentrations poses well-known humanhealth and ecological risks $(1,2)$. Identifying sources of $\mathrm{NO}_{3}$ in groundwater is fundamental to developing effective management plans intended to reduce nitrogen $(\mathrm{N})$ inputs to the environment. Measurements of ${ }^{15} \mathrm{~N} /{ }^{14} \mathrm{~N}$ ratios are widely used to infer sources of $\mathrm{NO}_{3}{ }^{-}$in groundwater, such as fertilizer, soil, and manure (3-6).

Fertilizer and manure sources of $\mathrm{NO}_{3}{ }^{-}$commonly can be distinguished from each other on the basis of their $\delta^{15} \mathrm{~N}$ values. Distinguishing between fertilizer and natural (soil or geologic) sources of $\mathrm{NO}_{3}{ }^{-}$, or between natural and manure sources, is more complicated because of the potentially wide

* Corresponding author phone: (303)236-4882 x286; fax: (303)236-4912; e-mail: pmcmahon@usgs.gov.

Lakewood, Colorado.

‡ Reston, Virginia.

10.1021/es052229q Not subject to U.S. Copyright. Publ. 2006 Am. Chem. Soc. Published on Web 03/31/2006 range in $\delta^{15} \mathrm{~N}$ values of $\mathrm{NO}_{3}{ }^{-}$derived from natural $\mathrm{N}$. Values of $\delta^{15} \mathrm{~N}$ for soil and groundwater $\mathrm{NO}_{3}{ }^{-}$derived from natural sources range from at least -5 to $+15 \%$ or higher $(4,7-10)$ and extend well into the range of values considered to be characteristic of fertilizer and manure N. In general, concentrations of natural $\mathrm{NO}_{3}{ }^{-}$in groundwater are less than about $140 \mu \mathrm{M}$ (11), which is much smaller than the United States drinking-water standard of $714 \mu \mathrm{M}(10 \mathrm{mg} / \mathrm{L}$ as $\mathrm{N})$, but concentrations as large as 1500 to $7000 \mu \mathrm{M}$ have been noted in some arid and semiarid regions $(7,12)$. A further complicating factor is the presence of large natural $\mathrm{NO}_{3}{ }^{-}$ deposits in the soil and subsoil of some arid and semiarid areas $(13-15)$. These $\mathrm{NO}_{3}{ }^{-}$deposits can be mobilized by irrigation water, making it difficult to distinguish between anthropogenic and natural $\mathrm{NO}_{3}{ }^{-}$sources $(16,17)$.

The regionally extensive High Plains aquifer is located in the western United States. About $30 \%$ of the groundwater used for irrigation in the United States is pumped from this aquifer (18), thus supporting one of the largest agricultural economies in the country. Large natural $\mathrm{NO}_{3}{ }^{-}$deposits in the unsaturated zone are known to be mobilized by irrigation return flows $(16,19)$. In addition, about $10^{9} \mathrm{~kg}$ of fertilizer $\mathrm{N}$ are applied to High Plains cropland on an annual basis (20). These conditions could result in uncertainty as to the primary sources of $\mathrm{NO}_{3}{ }^{-}$contamination in the aquifer. The purpose of this study was to characterize regional patterns in the isotopic composition of natural and anthropogenic $\mathrm{NO}_{3}{ }^{-}$in the High Plains aquifer to make more accurate source assessments of groundwater $\mathrm{NO}_{3}{ }^{-}$contamination in this semiarid region.

\section{Experimental Section}

Study Area. The unconfined High Plains aquifer underlies an area of about $450000 \mathrm{~km}^{2}$ in parts of eight western States (Figure 1). Grassland became dominant in the High Plains during the Holocene (last 10000 years) as the climate shifted toward warmer, drier conditions. Today, the High Plains climate is semiarid and supports short- and mixed-grass prairie as well as one of the largest agricultural economies in the United States.

Materials and Methods. In 1999-2004, water samples for chemical and isotopic analyses were collected from 38 nested monitoring wells with $3-\mathrm{m}$-long screens installed along regional transects in the northern High Plains aquifer of Nebraska (NHP), central High Plains aquifer of Kansas (CHP), and southern High Plains aquifer of Texas (SHP; Figure 1). The wells are located along transects ranging in length from about 90 to $100 \mathrm{~km}$ that represent multiple flow paths in the aquifer. Unsaturated-zone thicknesses along the transects ranged from about 2 to $70 \mathrm{~m}$ and aquifer thicknesses ranged from about 50 to $230 \mathrm{~m}$. Well water was analyzed for numerous chemical and isotopic parameters including dissolved $\mathrm{NO}_{3}{ }^{-}, \mathrm{Cl}^{-}$, and $\mathrm{Br}^{-}$; dissolved gases $\left(\mathrm{Ne}, \mathrm{Ar}, \mathrm{O}_{2}, \mathrm{~N}_{2}\right)$; and multiple isotopes $\left({ }^{3} \mathrm{H}, \delta^{2} \mathrm{H}\left[\mathrm{H}_{2} \mathrm{O}\right], \delta^{18} \mathrm{O}\left[\mathrm{H}_{2} \mathrm{O}\right], \delta^{15} \mathrm{~N}\left[\mathrm{NO}_{3}{ }^{-}\right]\right.$, $\delta^{18} \mathrm{O}\left[\mathrm{NO}_{3}{ }^{-}\right], \delta^{15} \mathrm{~N}\left[\mathrm{~N}_{2}\right], \delta^{13} \mathrm{C}[\mathrm{DIC}]$, and $\left.{ }^{14} \mathrm{C}[\mathrm{DIC}]\right)$. Parameters and methods for sample collection and analysis are described in McMahon et al. (21). For $\mathrm{NO}_{3}{ }^{-}$, the $\mathrm{N}$ and $\mathrm{O}$ isotopic compositions were analyzed using a bacterial reduction method with typical reproducibilities of 0.3 and $0.6 \%$ o $(2 \sigma)$ for $\delta^{15} \mathrm{~N}$ and $\delta^{18} \mathrm{O}$, respectively $(22-24)$. Nitrate concentrations were analyzed using a cadmium-reduction method with a detection limit of $4 \mu \mathrm{M}(0.06 \mathrm{mg} / \mathrm{L}$ as $\mathrm{N})(25)$ and a reproducibility of 6 percent $(2 \sigma)$ based on analyses of replicate samples. Chemical and isotopic data for transect wells analyzed in this paper are listed in the Supporting Information. These transect data are compared with $\mathrm{NO}_{3}{ }^{-}$concen-

VOL. 40, NO. 9, 2006 / ENVIRONMENTAL SCIENCE \& TECHNOLOGY - 2965 


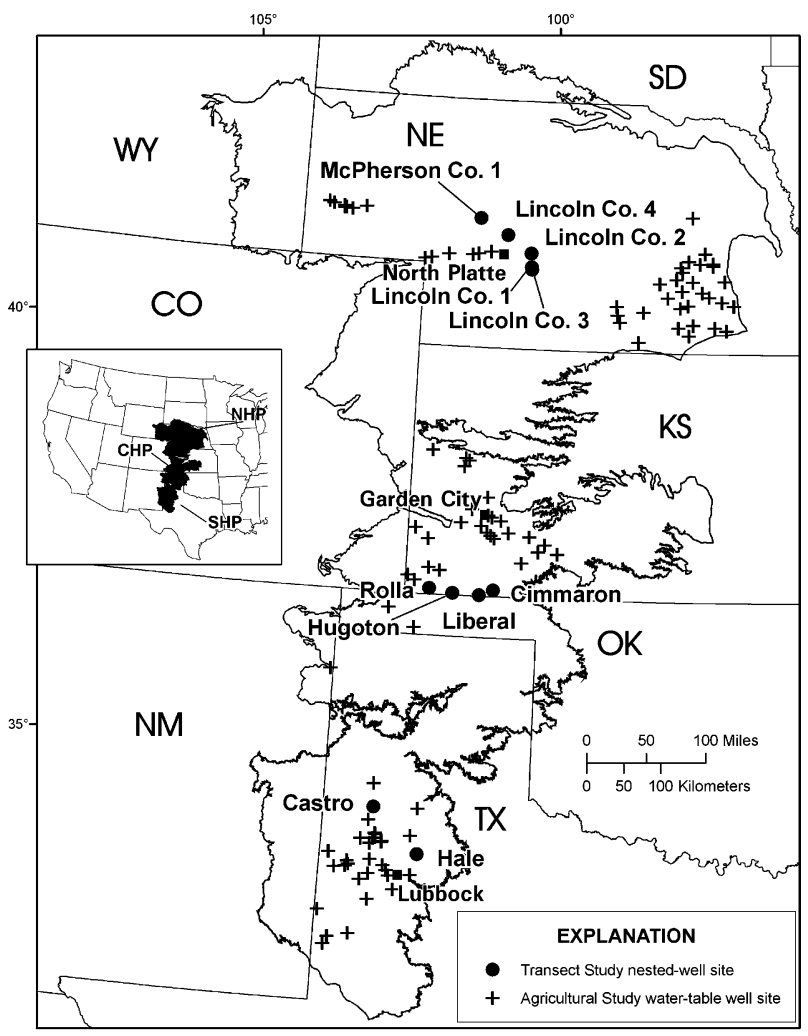

FIGURE 1. Location of the High Plains aquifer in the western United States. NHP, northern High Plains; CHP, central High Plains; SHP, southern High Plains.

trations and $\left.\delta^{15} \mathrm{~N} \mathrm{NO}_{3}{ }^{-}\right]$values from 103 monitoring wells with 3- to 6-m-long screens near the water table that were installed for investigations of agricultural effects on groundwater quality in the High Plains $(26,27)$.

\section{Results and Discussion}

Samples from the transect and water-table wells were characterized as modern recharge or paleorecharge, according to their ${ }^{3} \mathrm{H}$ content. Modern recharge was defined as water containing $>0.5 \mathrm{TU}$ of ${ }^{3} \mathrm{H}$ ( $<50$ years old). Paleorecharge was further characterized by using the ${ }^{14} \mathrm{C}$ content of dissolved inorganic carbon in groundwater to estimate its radiocarbon age. Radiocarbon ages were adjusted for carbon sources and sinks along flow paths by using chemical and isotopic data from the wells, as previously reported for the High Plains aquifer $(21,28)$.

Regional Isotopic Patterns. Denitrification in the saturated zone could affect the $\mathrm{N}$ isotopic composition of the groundwater $\mathrm{NO}_{3}{ }^{-}$and must be accounted for to compare the isotopic composition of $\mathrm{NO}_{3}{ }^{-}$from different sources. For the transect wells, denitrification in the saturated zone was estimated from analyses of $\mathrm{Ne}-\mathrm{Ar}$ recharge temperatures and $\mathrm{N}_{2}$ concentrations (21). Both the initial concentration and the initial isotopic composition of $\mathrm{NO}_{3}{ }^{-}$in recharge were reconstructed by combining data for reactant $\mathrm{NO}_{3}{ }^{-}$and product excess $\mathrm{N}_{2}$ gas in denitrified groundwater samples $(12,29)$. Samples from the agricultural water-table wells contained $>60 \mu \mathrm{M}(>2 \mathrm{mg} / \mathrm{L}) \mathrm{O}_{2}$, so they are not expected to have undergone substantial denitrification $(21,29,30)$.

The SHP contained an $\sim 6000$-year record, and the CHP and NHP each contained $\sim 12000$-year records of $\mathrm{NO}_{3}{ }^{-}$ concentrations and $\delta^{15} \mathrm{~N}$ values in paleorecharge. Most of the samples of paleorecharge contained $<0.3 \mathrm{TU}^{3} \mathrm{H}$ and had radiocarbon ages $>1000$ years; therefore, $\mathrm{NO}_{3}{ }^{-}$in those samples was assumed to be derived from natural sources. Initial $\mathrm{NO}_{3}{ }^{-}$concentrations in paleorecharge ranged from

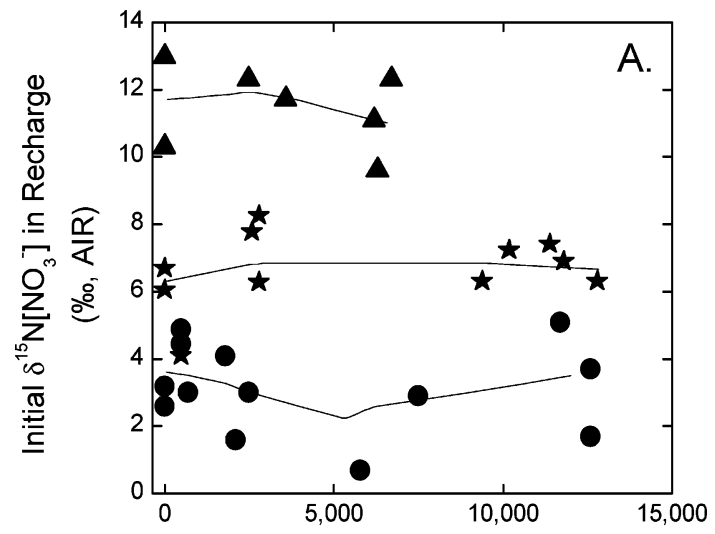

Adjusted Radiocarbon Age $\left({ }^{14} \mathrm{C}\right.$ Years BP)

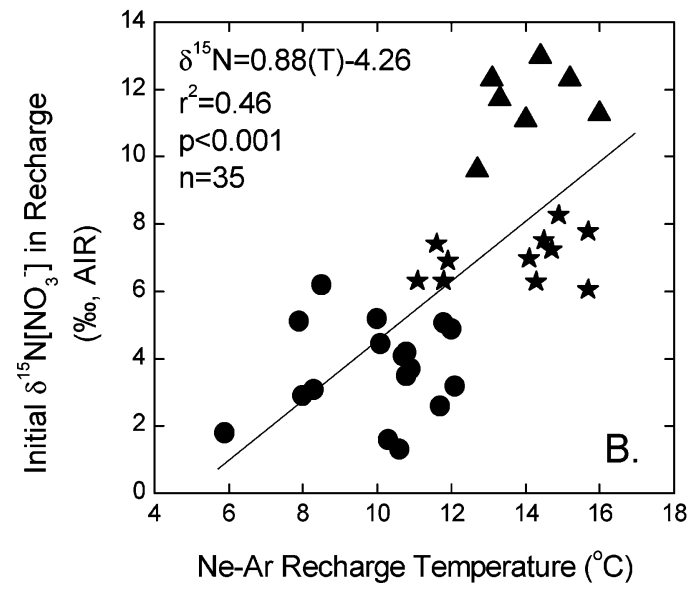

FIGURE 2. Initial $\delta^{15} \mathrm{~N}$ values of $\mathrm{NO}_{3}{ }^{-}$in recharge as a function of (A) radiocarbon age and (B) $\mathrm{Ne}-\mathrm{Ar}$ recharge temperature. Initial $\delta^{15} \mathrm{~N}$ values were obtained by correcting measured $\delta^{15} \mathrm{~N}$ values in samples from the transect wells for denitrification effects produced in the aquifer $(12,21,29)$. Solid circles, stars, and triangles represent the NHP, CHP, and SHP, respectively. The lines in (A) are LOWESS smooths of the data. Median precision (2 $\sigma$ ) estimates for the variables are: radiocarbon age $\left( \pm 1800{ }^{14} \mathrm{C}\right.$ years), $\delta^{15} \mathrm{~N}( \pm 0.8 \% 0)$, and $\mathrm{Ne}-\mathrm{Ar}$ recharge temperature $\left( \pm 1.0^{\circ} \mathrm{C}\right)$.

about 30 to $300 \mu \mathrm{M}$, with a median of $155 \mu \mathrm{M}$ and were significantly different only between the CHP and the SHP (at $\alpha=0.05$, Tukey-Kramer multiple comparison test). The median precision estimate for initial $\mathrm{NO}_{3}{ }^{-}$concentrations is $\pm 14 \mu \mathrm{M}(2 \sigma)$. The median concentration of excess $\mathrm{N}_{2}-\mathrm{N}$ from denitrification, $22 \mu \mathrm{M}$, represents about $15 \%$ of the median initial $\mathrm{NO}_{3}{ }^{-}$concentration, indicating that denitrification effects in groundwater generally were small.

Initial $\delta^{15} \mathrm{~N}$ values for $\mathrm{NO}_{3}{ }^{-}$in paleorecharge ranged from 1.3 to $12.3 \%$ o (Figure $2 \mathrm{~A}$ ). The median precision estimate for initial $\delta^{15} \mathrm{~N}$ values is $\pm 0.8 \%$ o $(2 \sigma)$. The $\delta^{15} \mathrm{~N}$ values were significantly different among the three regions and increased systematically from north to south. Median $\delta^{15} \mathrm{~N}$ values for the NHP, CHP, and SHP are 3.5, 7.0, and $11.7 \%$, respectively. Regional isotopic gradients in natural $\mathrm{NO}_{3}{ }^{-}$such as these have not previously been recognized in groundwater, yet they might have important implications with respect to the identification of anthropogenic $\mathrm{NO}_{3}{ }^{-}$in the hydrologic cycle in the High Plains by isotope techniques.

Nitrate concentrations in modern recharge under the irrigated fields ranged from 46 to $7570 \mu \mathrm{M}$ (Figure 3), with a median of $506 \mu \mathrm{M}$. In each region, $\mathrm{NO}_{3}{ }^{-}$concentrations in modern recharge were significantly larger than the concentrations in paleorecharge. Substantial amounts of $\mathrm{NO}_{3}{ }^{-}$, presumably leached from the soil zone during the Holocene, still reside in the subsoil in parts of the High Plains $(15,16)$. Mobilization of those subsoil $\mathrm{NO}_{3}{ }^{-}$reservoirs by irrigation 

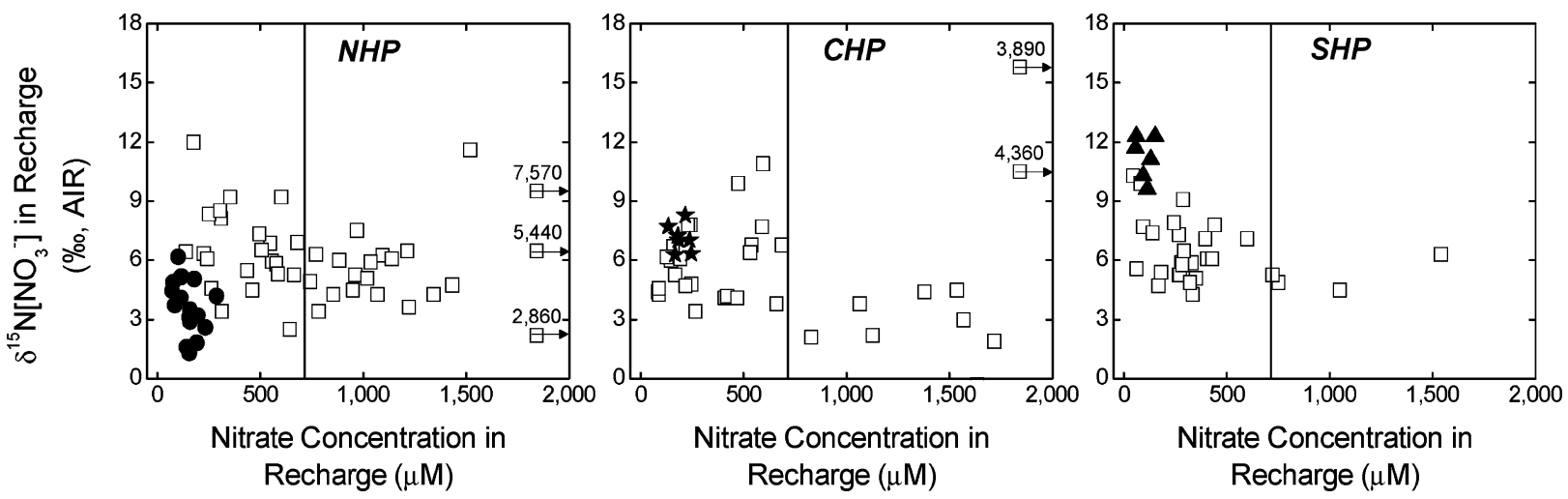

FIGURE 3. Initial $\mathrm{NO}_{3}{ }^{-}$concentrations and $\delta^{15} \mathrm{~N}$ values in paleorecharge (solid symbols) and measured $\mathrm{NO}_{3}{ }^{-}$concentrations and $\delta^{15} \mathrm{~N}$ values in modern recharge under irrigated fields (open squares) in the NHP, CHP, and SHP. Initial concentration and isotope values were obtained by correcting measured values in samples from the transect wells for denitrification effects produced in the aquifer (12, 21, 29). Modern recharge ( $<50$ years) samples were not corrected for denitrification effects because they contained dissolved $\mathrm{O}_{2}$ concentrations $>60 \mu \mathrm{M}$ (>2 mg/L). Vertical lines indicate the U.S. Environmental Protection Agency drinking water standard for $\mathrm{NO}_{3}{ }^{-}-\mathrm{N}$. Data for modern recharge from Bruce et al. (26) and U.S. Geological Survey (27).

return flow $(16,19)$, or by changes in climate $(15)$, could theoretically produce $\mathrm{NO}_{3}{ }^{-}$concentrations at the water table that are larger than any of the concentrations measured under the irrigated fields. Furthermore, the collective range in natural $\delta^{15} \mathrm{~N}\left[\mathrm{NO}_{3}{ }^{-}\right]$values in paleorecharge, 1.3 to $12.3 \%$, spans the range that might be interpreted as evidence for fertilizer and animal-waste sources of $\mathrm{NO}_{3}{ }^{-}$in anthropogenically disturbed areas $(3,5)$. However, $\delta^{15} \mathrm{~N}$ values for $\mathrm{NO}_{3}{ }^{-}$in modern recharge under fields that were irrigated for at least 20 years in the CHP and SHP were, for the most part, distinctly different from those of paleorecharge when viewed in the overall regional context (Figure 3). In each of those regions, $\mathrm{NO}_{3}{ }^{-}$in modern recharge with the largest concentrations apparently was derived primarily from sources other than natural N. The most likely sources are fertilizer and manure (yielding $\mathrm{NO}_{3}{ }^{-}$with relatively low and high $\delta^{15} \mathrm{~N}$ values, respectively) applied to those fields during their modern irrigation history. The data show that natural subsoil $\mathrm{NO}_{3}{ }^{-}$reservoirs, if originally present under those irrigated fields, apparently have not reached the water table yet or may have only a transient effect on groundwater quality when mobilized by infiltrating irrigation water. In the NHP, there was greater overlap in the $\delta^{15} \mathrm{~N}$ values for $\mathrm{NO}_{3}{ }^{-}$in paleorecharge and modern recharge (Figure 3). As a result, mobilization of natural subsoil $\mathrm{NO}_{3}{ }^{-}$reservoirs by irrigation return flow at some of the sites cannot be ruled out on the basis of these $\mathrm{N}$ isotope data. In each region, new inputs of $\mathrm{NO}_{3}{ }^{-}$from anthropogenic sources have tended to homogenize the pre-existing regional isotopic gradient, while increasing isotopic variability locally.

Sources of Natural $\mathrm{NO}_{3}{ }^{-}$. The sources of natural $\mathrm{NO}_{3}{ }^{-}$in groundwater can be quite variable and include reduced forms of $\mathrm{N}$ in rocks and minerals (geologic $\mathrm{N})(7,31)$, direct infiltration of atmospheric deposition (8), and atmospheric $\mathrm{N}$ (bulk deposition and fixed $\mathrm{N}_{2}$ ) that is cycled in the unsaturated zone prior to recharge $(14,32)$. Geologic $\mathrm{N}$ in some glacial sediments in the North American Great Plains is known to be an important source of $\mathrm{NO}_{3}{ }^{-}(7,16)$, but those identified areas are outside the study area.

Geologic $\mathrm{N}$ in the saturated zone in the study area is not believed to be a substantial source of $\mathrm{NO}_{3}{ }^{-}$, because $\mathrm{O}_{2}$ consumption in the groundwater can generally be accounted for by pyrite oxidation $(21,28)$, median concentrations of dissolved $\mathrm{NH}_{4}{ }^{+}$plus organic $\mathrm{N}(<7 \mu \mathrm{M})$ were small compared to initial $\mathrm{NO}_{3}{ }^{-}$concentrations $(155 \mu \mathrm{M})$, and the aquifer sediments generally contained very little organic matter $(<0.02-0.6$ wt \% organic C) $(21,28)$. Geologic $N$ in the unsaturated zone in the study area may not be a substantial source of $\mathrm{NO}_{3}{ }^{-}$either on the basis of small KCl-extractable $\mathrm{NH}_{4}{ }^{+}$concentrations (median $=0.4 \mu \mathrm{g} / \mathrm{g}$ as $\mathrm{N}, n=58$ ) in unsaturated-zone sediments from six High Plains sites (19, 33). For comparison, average $\mathrm{KCl}$-extractable $\mathrm{NH}_{4}{ }^{+}$concentrations were $20-145 \mu \mathrm{g} / \mathrm{g}$ as $\mathrm{N}$ in some Great Plains subsoil sediments that are known $\mathrm{NO}_{3}{ }^{-}$sources $(7,16)$. If these interpretations regarding geologic $\mathrm{N}$ are correct, then atmospheric $\mathrm{N}$ may be the primary source of natural groundwater $\mathrm{NO}_{3}{ }^{-}$in the study area.

Values of $\delta^{18} \mathrm{O}\left[\mathrm{NO}_{3}{ }^{-}\right]$for transect samples that were unaffected by denitrification in the aquifer ranged from about -5 to $+5 \%$ ond are equal to or slightly less than the expected values for $\mathrm{NO}_{3}{ }^{-}$produced by microbial nitrification in the soil zone, assuming the $\mathrm{O}$ was derived from a 2:1 proportion of unfractionated $\mathrm{H}_{2} \mathrm{O}-\mathrm{O}(-11$ to $-5 \%$ o) and atmospheric $\mathrm{O}_{2}-\mathrm{O}(+23.8 \%$ o $)$ in the soil zone $(34,35)$ (Figure $\left.4 \mathrm{~A}\right)$. These data indicate that $\mathrm{NO}_{3}{ }^{-}$in Holocene recharge did not come directly from $\mathrm{NO}_{3}{ }^{-}$in atmospheric deposition, which would have substantially larger $\delta^{18} \mathrm{O}$ values $(8,36)$, but instead was formed in the soil from reduced N. Presumably, this reduced $\mathrm{N}$ was derived from atmospheric deposition and (or) fixed $\mathrm{N}_{2}$ that was incorporated into the soil and plant N. This interpretation is consistent with recent work showing that directly deposited atmospheric $\mathrm{NO}_{3}{ }^{-}$dominates microbial $\mathrm{NO}_{3}{ }^{-}$in the soil zone only in extremely dry environments such as the Atacama Desert (36).

N Isotopic Fractionation. The initial $\delta^{15} \mathrm{~N}$ values for Holocene recharge $(1.3-12.3 \%$ o) are equal to or higher than expected for atmospheric $\mathrm{N}$ deposition or $\mathrm{N}_{2}$ fixation, which typically have average values around $0 \pm 4 \%$ o $(4,5)$. The apparent isotopic enrichment in some of the samples might result from fractionating losses of $\mathrm{N}$ from the soil prior to recharge, which could vary in relation to climate, soils, vegetation, topography, seasonal timing of recharge, and other factors. Alternatively, the apparent isotopic enrichment might reflect systematic regional differences in the isotopic composition of atmospheric $\mathrm{N}$ inputs, in which case fractionating $\mathrm{N}$ losses would be relatively less important. The $\mathrm{N} / \mathrm{Cl}$ ratios in groundwater and atmospheric deposition have been used to examine $\mathrm{NO}_{3}{ }^{-}$production (14) and $\mathrm{N}$ loss (32) in soils. This approach assumes that $\mathrm{Cl}^{-}$is a conservative indicator of atmospheric deposition; therefore, it only applies to those groundwater samples that did not have deep $\mathrm{Cl}^{-}$ sources and that have atmospheric $\mathrm{Br}^{-} / \mathrm{Cl}^{-}$ratios.

Median $\mathrm{Cl}^{-}$concentrations in modern (1984-2004) wet deposition collected at nine National Atmospheric Deposition Program (NADP) sites in or near the NHP, CHP, and SHP are $1.92,2.74$, and $3.12 \mu \mathrm{M}$, respectively (NADP sites SD08, WY99, 

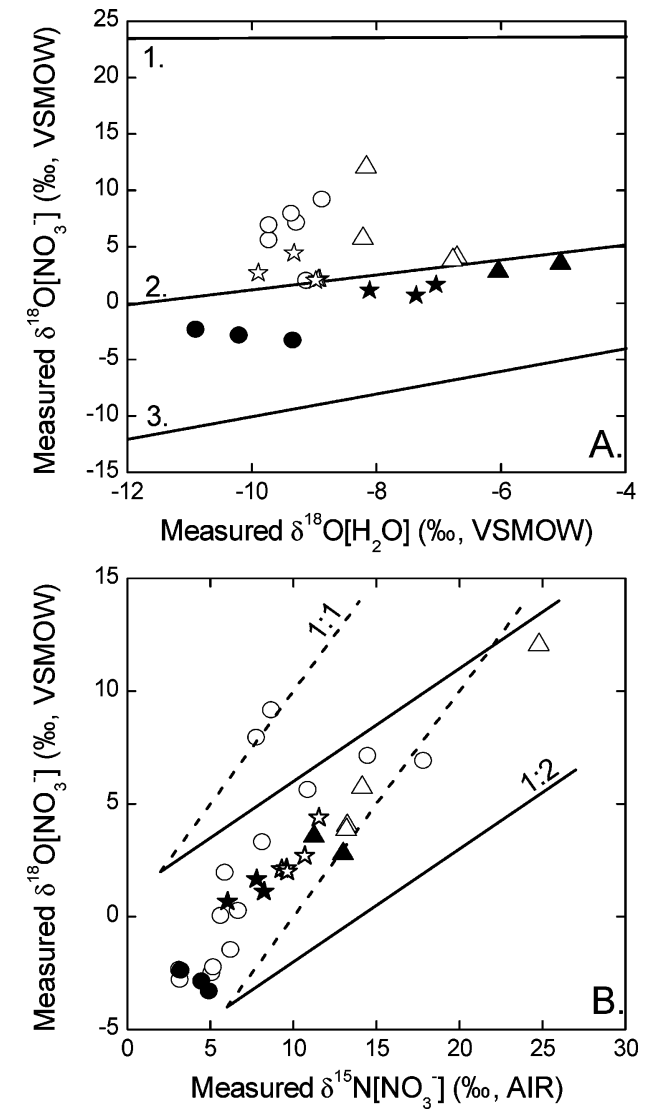

FIGURE 4. Measured $\delta^{18} 0$ values of $\mathrm{NO}_{3}{ }^{-}$in groundwater as a function of the (A) measured $\delta^{18} 0$ values of groundwater and (B) measured $\delta^{15} \mathrm{~N}$ values of $\mathrm{NO}_{3}{ }^{-}$in groundwater. Circles, stars, and triangles represent the NHP, CHP, and SHP, respectively. Solid symbols represent samples unaffected by denitrification in the aquifer, and open symbols represent samples affected by denitrification in the aquifer. (A) Line 1 is defined as $\delta^{18} 0\left[\mathrm{NO}_{3}{ }^{-}\right]=$ $\delta^{18} 0\left[\mathrm{O}_{2}\right.$-air], line 2 is defined as $\delta^{18} 0\left[\mathrm{NO}_{3}{ }^{-}\right]=2 /{ }_{3} \delta^{18} \mathrm{O}\left[\mathrm{H}_{2} \mathrm{O}\right]+$ $1 / 3 \delta^{18} 0\left[0_{2}-\right.$ air], and line 3 is defined as $\delta^{18} 0\left[\mathrm{NO}_{3}{ }^{-}\right]=\delta^{18} 0\left[\mathrm{H}_{2} \mathrm{O}\right]$. (B) The lines indicate the range of fractionation trends reported for $\mathrm{NO}_{3}{ }^{-}$reduction $(45,46)$.

NE99, CO01, KS32, OK29, TX02, TX04, TX22) (37). Bromide was not measured in the NADP samples, but median $\mathrm{Br}^{-} / \mathrm{Cl}^{-}$mole ratios in meteoric groundwater containing $<425$ $\mu \mathrm{M}(<15 \mathrm{mg} / \mathrm{L}) \mathrm{Cl}^{-}$in each High Plains region ranged from 0.0039 to $0.0053 \mu \mathrm{M}$ (27), which correspond to median $\mathrm{Br}^{-}$ concentrations in wet deposition of 0.010 to $0.013 \mu \mathrm{M}$. Most of the samples from the transect wells have $\mathrm{Br}^{-} / \mathrm{Cl}^{-}$ratios similar to those in modern atmospheric deposition (Figure 5A). Three samples containing $\mathrm{Cl}^{-}$concentrations $>50000$ $\mu \mathrm{M}$ plot well below the curves for modern atmospheric deposition, indicating that those samples were enriched in $\mathrm{Cl}^{-}$from deep saline sources $(21,28)$.

The $\left[\mathrm{NO}_{3}{ }^{-}+\mathrm{NH}_{4}{ }^{+}\right] / \mathrm{Cl}^{-}$mole ratios in atmospheric deposition collected at the nine NADP sites were relatively small and constant during the first five years of sample collection, beginning in 1984, and ranged from about 7 to 15 . Subsequently, the ratios at some of the sites increased so that by 2004 they ranged from about 7 to 45 . Thus, the ratios during the early time period were used to characterize modern atmospheric deposition with relatively small impacts from anthropogenic $\mathrm{N}$ inputs.

Almost all of the $\mathrm{NO}_{3}{ }^{-} / \mathrm{Cl}^{-}$mole ratios in paleorecharge are less than the $\left[\mathrm{NO}_{3}{ }^{-}+\mathrm{NH}_{4}{ }^{+}\right] / \mathrm{Cl}^{-}$ratios for modern atmospheric deposition (Figure $5 \mathrm{~B} ; \mathrm{NH}_{4}{ }^{+}$concentrations in groundwater were below detection, $<5 \mu \mathrm{M}$ ). Furthermore, there is an inverse relation between the $\delta^{15} \mathrm{~N}\left[\mathrm{NO}_{3}{ }^{-}\right]$values
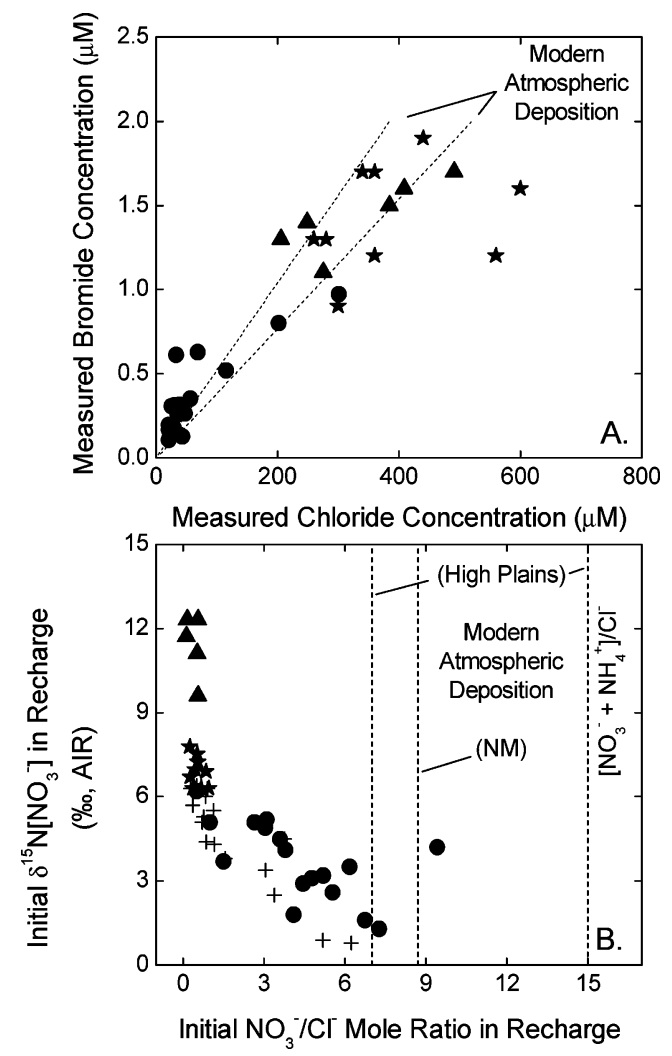

FIGURE 5. (A) Measured $\mathrm{Br}^{-}$and $\mathrm{Cl}^{-}$concentrations in samples from the transect wells and (B) initial $\left.\delta^{15} \mathrm{~N} \mathrm{NO}_{3}{ }^{-}\right]$values as a function of initial $\mathrm{NO}_{3}{ }^{-} / \mathrm{Cl}^{-}$mole ratios in paleorecharge. Solid circles, stars, and triangles represent the NHP, CHP, and SHP, respectively. Crosses represent old groundwater from central New Mexico (32). The dashed lines in (A) represent the range of median $\mathrm{Br}^{-} / \mathrm{Cl}^{-}$mole ratios in modern wet deposition in the three High Plains regions. The dashed lines in (B) represent the range of median $\left[\mathrm{NO}_{3}{ }^{-}+\right.$ $\left.\mathrm{NH}_{4}{ }^{+}\right] / \mathrm{Cl}^{-}$mole ratios in modern wet deposition (High Plains) (37) or average bulk deposition in central New Mexico (NM) (32).

and $\mathrm{NO}_{3}{ }^{-} / \mathrm{Cl}^{-}$ratios in paleorecharge that is qualitatively consistent with fractionating losses of $\mathrm{N}$ increasing from north to south in the High Plains (Figure 5B). Nitrogen isotopic enrichment with decreasing $\mathrm{NO}_{3}{ }^{-} / \mathrm{Cl}^{-}$ratios also was reported for old groundwater from central New Mexico (32) (Figure 5B). In contrast, Edmunds and Gaye (14) reported that $\mathrm{NO}_{3}{ }^{-} / \mathrm{Cl}^{-}$ratios in groundwater from an aquifer in Senegal were substantially larger than those for modern atmospheric deposition and concluded that large concentrations of natural $\mathrm{NO}_{3}{ }^{-}$in that aquifer resulted from $\mathrm{NO}_{3}{ }^{-}$ production in the soil zone, possibly related to the growth of leguminous plants. Our comparison of $\mathrm{NO}_{3}{ }^{-} / \mathrm{Cl}^{-}$ratios in groundwater to $\left[\mathrm{NO}_{3}{ }^{-}+\mathrm{NH}_{4}{ }^{+}\right] / \mathrm{Cl}^{-}$ratios in atmospheric deposition assumes that ratios in wet deposition were similar to those in bulk deposition. Data from New Mexico indicate that $\left[\mathrm{NO}_{3}{ }^{-}+\mathrm{NH}_{4}{ }^{+}\right] / \mathrm{Cl}^{-}$ratios in bulk deposition may have been about $20 \%$ smaller than the ratios in wet deposition (32). Nevertheless, most of the $\mathrm{NO}_{3}{ }^{-} / \mathrm{Cl}^{-}$ratios in High Plains groundwater still would be less than those for atmospheric deposition if they were smaller by $20 \%$. Our analysis also is limited by a lack of information on the temporal variability in atmospheric $\left[\mathrm{NO}_{3}{ }^{-}+\mathrm{NH}_{4}{ }^{+}\right] / \mathrm{Cl}^{-}$ratios and the contribution of $\mathrm{N}_{2}$ fixation to soils in the High Plains during the Holocene.

The $\mathrm{N}$ and $\mathrm{O}$ isotope data for samples from the transect wells that were unaffected by denitrification in the aquifer (Figure 4, solid symbols) are consistent with both denitrification and $\mathrm{NH}_{3}$ volatilization, having contributed to fractionating losses of $\mathrm{N}$ prior to recharge. Seasonally flooded playas are important recharge areas in the SHP (38), and 
saturated playa sediments can promote denitrification (39). Denitrification could have been relatively less important in the NHP recharge areas if well-drained soils in the Nebraska Sand Hills (40), where most of the NHP wells are located, maintained low soil-water contents. Because much of the variation in $\delta^{18} \mathrm{O}\left[\mathrm{NO}_{3}{ }^{-}\right]$can be related to variation in $\delta^{18} \mathrm{O}\left[\mathrm{H}_{2} \mathrm{O}\right]$ during nitrification (Figure $4 \mathrm{~A}$, solid symbols), it appears that $\mathrm{NH}_{3}$ volatilization may have been at least as important as soil denitrification in contributing to fractionating $\mathrm{N}$ losses. The possible importance of $\mathrm{NH}_{3}$ volatilization is consistent with the observation that increases in $\delta^{15} \mathrm{~N}$ values from north to south were generally accompanied by increased recharge temperatures (Figure $2 \mathrm{~B}$ ) and carbonate content of High Plains soils. Warm temperatures and calcareous soils promote $\mathrm{NH}_{3}$ volatilization (3). Volatilization may have been relatively less important in the NHP because of lower temperatures (Figure 2B) and slightly acidic soils (40) in the NHP recharge areas. The apparent enrichment factors that would be consistent with the inverse relation between $\delta^{15} \mathrm{~N}$ and $\mathrm{NO}_{3}{ }^{-} / \mathrm{Cl}^{-}$in Figure $5 \mathrm{~B}$ would be approximately -10 to $-2 \%$. These enrichment factors are smaller than those commonly reported for $\mathrm{NH}_{3}$ volatilization and denitrification in closed systems (about -30 to $-20 \%$ o) but within the range of possibilities in heterogeneous open systems $(41,42)$, such as partially or intermittently saturated soils.

Presumably, fractionating processes in the unsaturated zone were more active in the soil zone than in the subsoil, even though unsaturated zones at the transect sites attained thicknesses of $70 \mathrm{~m}$. Numerical simulations of $\mathrm{N}_{2} \mathrm{O}$ production in thick unsaturated zones at nine sites in the High Plains indicated that production in the subsoil was negligible compared to production in the soil zone (top $2 \mathrm{~m}$ ) (43). Nitrous oxide can be produced by nitrification and denitrification. Furthermore, measurements of unsaturated-zone gases in the High Plains showed that $\mathrm{Ar} / \mathrm{N}_{2}$ ratios in the deep unsaturated zone were similar to atmospheric values (0.012) $(33,44)$, indicating that subsoil denitrification may not have been substantial.

Although the regional differences in the isotopic composition of $\mathrm{NO}_{3}{ }^{-}$in Figure $5 \mathrm{~B}$ can be rationalized on the basis of climate and soil processes, it is not clear from this limited dataset if the patterns really reflect regional climate gradients or if they also include local effects in each of the three areas. Densmore and Böhlke (10) report variations of $\delta^{15} \mathrm{~N}$ from about +8 to $+15 \%$ o in natural soil $\mathrm{NO}_{3}{ }^{-}$from ridges, slopes, and playa bottoms in a small area of the western Mojave Desert, consistent with an overall enrichment of ${ }^{15} \mathrm{~N}$ in warm dry environments but indicating variability that may be related locally to topographic variations in moisture or ecosystems. Plummer et al. (32) report variations of $\delta^{15} \mathrm{~N}$ from about +1 to $+8 \%$ o in natural $\mathrm{NO}_{3}{ }^{-}$in old groundwater from central New Mexico (Figure 5B), apparently related to varying degrees of $\mathrm{N}$ depletion and isotopic fractionation in subregions with different vegetation prior to recharge. In these cases, the highest $\delta^{15} \mathrm{~N}$ values are in areas more likely to have been wetted more frequently or to have more vegetation. Alternative causes of $\mathrm{N}$ isotopic differences also could include varying amounts of $\mathrm{N}_{2}$ fixation (resulting in larger inputs of $\mathrm{N}$ with relatively low $\delta^{15} \mathrm{~N}$ values) and isotopic fractionation during nitrification (yielding relatively low $\delta^{15} \mathrm{~N}$ values for $\mathrm{NO}_{3}{ }^{-}$where excess $\mathrm{NH}_{4}{ }^{+}$is present).

Although the $\delta^{15} \mathrm{~N}$ values of modern anthropogenic $\mathrm{NO}_{3}$ are highly variable, they do not exhibit the same systematic regional variation as the Holocene $\mathrm{NO}_{3}{ }^{-}$. The relative absence of regional variation in the anthropogenic $\mathrm{NO}_{3}{ }^{-}$may be related to the much higher leaching fluxes that result from higher $\mathrm{N}$ loads and higher recharge rates, especially from irrigation (19), effects from cultivation, or differences in vegetation types and density between natural grasslands and irrigated cropland.

\section{Acknowledgments}

This work was funded by the USGS National Water-Quality Assessment (NAWQA) Program and National Research Program. Assistance in the laboratory was provided by Tyler Coplen, Janet Hannon, and Haiping Qi. We thank J. M. Holloway, T. R. Seastedt, M. A. Walvoord, and three anonymous reviewers for comments on earlier drafts of this manuscript.

\section{Supporting Information Available}

Table SI- 1 contains the chemical and isotopic data used in the study. This material is available free of charge via the Internet at http://pubs.acs.org.

\section{Literature Cited}

(1) Fan, A. M.; Steinberg, V. E. Health implications of nitrate and nitrite in drinking water: An update on methemoglobinemia occurrence and reproductive and developmental toxicity. Regul. Toxicol. Pharmacol. 1996, 23, 35.

(2) Galloway, J. N.; Aber, J. D.; Erisman, J. W.; Seitzinger, S. P.; Howarth, R. W.; Cowling, E. B.; Cosby, B. J. The nitrogen cascade. BioScience 2003, 53, 341.

(3) Kreitler, C. W. Nitrogen-isotope ratio studies of soils and groundwater nitrate from alluvial fan aquifers in Texas. J. Hydrol. 1979, 42, 147.

(4) Heaton, T. H. E. Isotopic studies of nitrogen pollution in the hydrosphere and atmosphere: A review. Chem. Geol. 1986, 59, 87.

(5) Kendall, C. Tracing nitrogen sources and cycling in catchments. In Isotope Tracers in Catchment Hydrology; Kendall, C. McDonnell, J. J., Eds.; Elsevier: New York, 1998.

(6) Böhlke, J. K. Groundwater recharge and agricultural contamination. Hydrogeol. J. 2002, 10, 153. [Erratum, Hydrogeol. J. 2002 10, 438].

(7) Hendry, M. J.; McCready, R. G. L.; Gould, W. D. Distribution, source, and evolution of nitrate in a glacial till of southern Alberta, Canada. J. Hydrol. 1984, 70, 177.

(8) Durka, W.; Schulze, E. D.; Gebauer, G.; Voerkelius, S. Effects of forest decline on uptake and leaching of deposited nitrate determined from ${ }^{15} \mathrm{~N}$ and ${ }^{18} \mathrm{O}$ measurements. Nature 1994, 372, 765.

(9) Böhlke, J. K.; Ericksen, G. E.; Revesz, K. Stable isotope evidence for an atmospheric origin of desert nitrate deposits in northern Chile and southern California, U.S.A. Chem. Geol. 1997, 136, 135.

(10) Densmore, J. N.; Böhlke, J. K. Use of nitrogen isotopes to determine sources of nitrate contamination in two desert basins in California. In Proceedings of the Symposium on Interdisciplinary Perspectives on Drinking Water Risk Assessment and Management, Publication no. 260; IAHS: Santiago, Chile, 2000; p 63.

(11) Mueller, D. K.; Helsel, D. R.. Nutrients in the nation's water-Too much of a good thing? Geol. Surv. Circ. (U.S.) 2002, 1136.

(12) Heaton, T. H. E.; Talma, A. S.; Vogel, J. C. Origin and history of nitrate in confined ground water in the western Kalahari. $J$. Hydrol. 1983, 62, 243.

(13) Ericksen, G. E. Geology and origin of the Chilean nitrate deposits. U.S. Geol. Surv. Prof. Pap. 1981, 1188.

(14) Edmunds, W. M.; Gaye, C. B. Naturally high nitrate concentrations in ground waters from the Sahel. J. Environ. Qual. 1997, $26,1231$.

(15) Walvoord, M. A.; Phillips, F. M.; Stonestrom, D. A., Evans, R. D.; Hartsough, P. C.; Newman, B. D.; Striegl, R. G. A reservoir of nitrate beneath desert soils. Science 2003, 302, 1021.

(16) Boyce, J. S.; Muir, J.; Edwards, A. P.; Seim, E. C.; Olson, R. A. Geologic nitrogen in Pleistocene loess of Nebraska. J. Environ. Qual. 1976, 5, 93.

(17) Stonestrom, D. A.; Prudic, D. E.; Laczniak, R. J.; Akstin, K. C.; Boyd, R. A.; Henkelman, K. K. Estimates of deep percolation beneath native vegetation, irrigated fields, and the Amargosa River channel, Amargosa Desert, Nye County, Nevada. OpenFile Report - U.S. Geol. Surv. 2003, 03-104.

(18) Maupin, M. A.; Barber, N. L. Estimated withdrawals from principal aquifers in the United States, 2000. Geol. Surv. Circ. (U.S.) 2005, 1279

(19) McMahon, P. B.; Dennehy, K. F.; Bruce, B. W.; Böhlke, J. K.; Michel, R. L.; Gurdak, J. J.; Hurlbut, D. B. Storage and Transit Time of Chemicals in Thick Unsaturated Zones Under Range- 
land and Irrigated Cropland, High Plains, USA. Water Resour. Res. 2006, 42, W03413, doi:10.1029/2005WR004417.

(20) Alexander, R. B.; Smith, R. A. County-Level Estimates of Nitrogen and Phosphorus Fertilizer Use in the United States, 1945 to 1985. Open-File Report - U.S. Geol. Surv. 1990, 90-130.

(21) McMahon, P. B.; Böhlke, J. K.; Christenson, S. C. Geochemistry, radiocarbon ages, and paleorecharge conditions along a transect in the central High Plains aquifer, southwestern Kansas, USA. Appl. Geochem. 2004, 19, 1655.

(22) Sigman, D. M.; Casciotti, K. L.; Andreani, M.; Barford, C.; Galanter, M.; Böhlke, J. K. A bacterial method for the nitrogen isotopic analysis of nitrate in seawater and freshwater. Anal. Chem. 2001, 73, 4145.

(23) Casciotti, K. L.; Sigman, D. M.; Hastings, M.; Böhlke, J. K.; Hilkert, A. Measurement of the oxygen isotopic composition of nitrate in seawater and freshwater using the denitrifier method. Anal. Chem. 2002, 74, 4905.

(24) Coplen, T. B.; Böhlke, J. K.; Casciotti, K. L. Using dual bacterial denitrification to improve $\delta^{15} \mathrm{~N}$ determinations of nitrates containing mass independent ${ }^{17} \mathrm{O}$. Rapid Commun. Mass Spectrom. 2004, 18, 245.

(25) Fishman, M. J. Methods of analysis by the U. S. Geological Survey National Water Quality Laboratory-Determination of inorganic and organic constituents in water and fluvial sediments. OpenFile Report - U.S. Geol. Surv. 1993, 93-125.

(26) Bruce, B. W.; Becker, M. F.; Pope, L. M.; Gurdak, J. J. Ground water quality beneath irrigated agriculture in the central High Plains aquifer, 1999-2000. Water-Resour. Invest. Rep. (U.S. Geol. Surv.) 2003, 03-4219.

(27) U.S. Geological Survey National Water Information System Web Site. http://waterdata.usgs.gov/nwis/qw.

(28) McMahon, P. B.; Böhlke, J. K.; Lehman, T. M., Vertical gradients in water chemistry and age in the southern High Plains aquifer, Texas, 2002. U.S. Geol. Surv. Scientific Invest. Rep. 2004, 20045053.

(29) Böhlke, J. K.; Wanty, R.; Tuttle, M.; Delin, G.; Landon, M. Denitrification in the recharge area and discharge area of a transient agricultural nitrate plume in a glacial outwash sand aquifer, Minnesota. Water Resour. Res. 2002, 38, doi: 10.1029/ 2001WR000663.

(30) Hiscock, K. M.; Lloyd, J. W.; Lerner, D. N. Review of natural and artificial denitrification of groundwater. Water Res. 1991, 25, 1099.

(31) Holloway, J. M.; Dahlgren, R. A.; Hansen, B.; Casey, W. H. Contribution of bedrock nitrogen to high nitrate concentrations in stream water. Nature 1998, 395, 785.

(32) Plummer, L. N.; Böhlke, J. K.; Doughten, M. W. Perchlorate in Pleistocene and Holocene groundwater in north-central New Mexico. Environ. Sci. Technol. 2006, 40, 1757.

(33) McMahon, P. B. Unpublished data.
(34) Anderson, K. K.; Hooper, A. B. $\mathrm{O}_{2}$ and $\mathrm{H}_{2} \mathrm{O}$ are each the source of one $\mathrm{O}$ in $\mathrm{NO}_{2}$ produced from $\mathrm{NH}_{3}$ by Nitrosomonas: ${ }^{15} \mathrm{~N}$ evidence. FEBS Lett. 1983, 164, 236.

(35) Hollocher, T. C. Source of oxygen atoms of nitrate in the oxidation of nitrite by Nitrobacter agilis and evidence against a $\mathrm{P}-\mathrm{O}-\mathrm{N}$ anhydride mechanism in oxidative phosphorylation. Arch. Biochem. Biophys. 1984, 233, 721.

(36) Michalski, G.; Böhlke, J. K.; Thiemens, M. Long-term atmospheric deposition as the source of nitrate and other salts in the Atacama Desert, Chile: New evidence from mass-independent oxygen isotopic compositions. Geochim. Cosmochim. Acta 2004, 68, 4023.

(37) National Atmospheric Deposition Program. http://nadp.sws. uiuc.edu/sites/ntnmap.asp?

(38) Scanlon, B. R.; Goldsmith, R. S. Field study of spatial variability in unsaturated flow beneath and adjacent to playas. Water Resour. Res. 1997, 2239.

(39) Fryar, A. E.; Macko, S. A.; Mullican, W. F.; Romanak, K. D.; Bennett, P. C. Nitrate reduction during ground water recharge, Southern High Plains, Texas. J. Contam. Hydrol. 2000, 40, 335.

(40) Lewis, D. T. Origin of properties of Sand Hills soils. In An Atlas of the Sand Hills, Atlas No. 5b; Bleed, A. S., Flowerday, C. A. Eds.; Nebraska Conservation and Survey Division, 1998, Lincoln, NE.

(41) Mariotti, A.; Landreau, A.; Simon, B. ${ }^{15} \mathrm{~N}$ isotope biogeochemistry and natural denitrification process in groundwater: Application to the chalk aquifer of northern France. Geochim. Cosmochim. Acta 1988, 52, 1869

(42) Brandes, J.A.; Devol, A. H. A global marine-fixed nitrogen isotopic budget-Implications for Holocene nitrogen cycling. Global Biogeochem. Cycles 2002, 16, 1120.

(43) Weeks, E. P.; McMahon P. B. Nitrous oxide production rates derived from measurements in the thick unsaturated zone of the High Plains aquifer, USA. Geol. Soc. Am. Annual Meeting, Salt Lake City, UT, October, 2005.

(44) Wood, W. W.; Petraitis, M. J. Origin and distribution of carbon dioxide in the unsaturated zone of the southern High Plains of Texas. Water Resour. Res. 1984, 20, 1193.

(45) Böttcher, J.; Strebel, O.; Voerkelius, S.; Schmidt, H. L. Using isotope fractionation of nitrate-nitrogen and nitrate-oxygen for evaluation of microbial denitrification in a sandy aquifer. $J$. Hydrol. 1990, 114, 413.

(46) Granger, J.; Sigman, D. M.; Needoba, J. A.; Harrison, P. J. Coupled nitrogen and oxygen isotope fractionation of nitrate during assimilation by cultures of marine phytoplankton. Limnol. Oceanogr. 2004, 49, 1763.

Received for review November 7, 2005. Revised manuscript received February 28, 2006. Accepted March 9, 2006.

ES052229Q 